Ilmu Pertanian (Agricultural Science)

Vol. 1 No. 3 December, 2016 : 105-110

Available online at http://journal.ugm.ac.id/jip

DOI: doi.org/10.22146/ipas.16349

\title{
Effects of Plant Growth Promoting Rhizobacteria (PGPR) on Growth and Yield of Shallot in Sandy Coastal Land
}

\author{
Sumiyati Tuhuteru ${ }^{1 *}$, Endang Sulistyaningsih ${ }^{1}$, Arif Wibowo ${ }^{2}$ \\ ${ }^{1}$ Department of Agronomy, Faculty of Agriculture, Universitas Gadjah Mada \\ Jln. Flora no. 1, Bulaksumur, Sleman, Yogyakarta 5528, Indonesia \\ ${ }^{2}$ Department of Plant Protection, Faculty of Agriculture, Universitas Gadjah Mada \\ Jln. Flora no. 1, Bulaksumur, Sleman, Yogyakarta 5528, Indonesia \\ *Corresponding email: sumiyati.tuhuteru@mail.ugm.ac.id
}

Received: $9^{\text {th }}$ November 2016 ; Revised: 29th December 2016; Accepted: $18^{\text {th }}$ August 2017

\begin{abstract}
The marginal sandy coastal land should be utilized to maintain production level of shallot. But for increasing the productivity of sandy coastal land, in the shallot cultivation should be applied biological fertilizers, such as Plant Growth Promoting Rhizobacteria (PGPR). The purpose of this research was to obtain the most effective isolate of PGPR (Plant Growth Promoting Rhizobacteria) to the growth of three shallot cultivars in the sandy coastal land. The research had been conducted in August-November 2015 at Samas sandy coastal land, Bantul. The Factorial treatments were assigned in Randomized Complete Block Design with three blocks as replications. The first factor was shallot cultivars consisted of Crok, Tiron and Tuk-tuk, while the second factor was the PGPR suspension, i.e. control (without PGPR), PGPR isolates BP25.2 (Bacillus methylotrophicus), BP25.6 (Bacillus amyloliquofaciens), BP25.7 (Bacillus subtilis), BrSM 4 (Burkholderiacepacia), and BrSG 5 (Burkholderiaseminalis). The data of growth and yield were analyzed using ANOVA with $\alpha=5 \%$, then followed by DMRT $\alpha 5 \%$. The result showed that Tiron cultivar was able to grow in sandy coastal land, proven from its good germination, high number of bulb, high fresh weight, and dry weight of bulb. Meanwhile, BP25.2 isolate was able to increase seed growth simultaneously of Tiron cultivar and BrSM 4 isolate was able to increase the chlorophyll content of Tuk-tuk cultivars.
\end{abstract}

Keywords: PGPR, Sandy Coastal Land, Shallot

\section{INTRODUCTION}

Shallots were a featured vegetable crops, which had long been intensively cultivated by farmers. In 2015 , shallots export soared by $219 \%$. Correspondingly, shallot imports fell $82 \%$ in the same period (Anonymous, 2015). In order to maintain production level of shallots, the use of marginal lands, such as sandy coastal land, needed to be expanded.

Sandy coastal land was included in the category of non-productive land. Land use would increase the need to settling the sandy soil,so availability was increasingly limited and expensive. Therefore, an alternative substitution of manure was needed (Rajiman et al., 2008). To achieve the productivity of shallot, the use of a biological fertilizer, combined with organic matter fertilizer,was expected to increase the productivity of sandy coastal land, thus would optimize and maintain shallots production in Indonesia, both in quality or quantity. One biological fertilizer used in the agricultural world is rhizosphere group of bacteria or often known Rhizobacteria Growing Plants or Plant Growth Promoting Rhizobacteria (PGPR).

PGPR application could benefit plant growth, either directly or indirectly. The direct effect of PGPR was based on its ability to provide and to mobilize or facilitate the absorption of various nutrients in the soil, as well as synthesizing and changing the phytohormone concentration. While the indirect effect was PGPR ability to suppress pathogens activity by producing various compounds or metabolites, such as antibiotics and siderophores (Kloepper et al., 1991; Kloepper, 1993; Glick, 1995).The purpose of this research was to obtain the most effective isolate of PGPR (Plant Growth Promoting Rhizobacteria) to the growth of three shallot cultivars in the sandy coastal land 


\section{MATERIALS AND METHODS}

The research was conducted in sandy coastal land Samas - Bantul, Yogyakarta, from August 2015 to June 2016, which began in the Laboratory of Plant Diseases, Faculty of Agriculture, Universitas Gadjah Mada. The research then proceed to the Laboratory of Plant Sciences, Faculty of Agriculture, Universitas Gadjah Mada.

The materials used in this research were shallot seeds from Crok, Tiron, and Tuk-tuk cultivars. PGPRs used were BP25.2 isolates (Bacillus methylotrophicus), BP25.6 (Bacillus amyloliquofaciens), BP25.7 (Bacillus subtilis), BrSM4 (Burkholderiacepacia), and BrSG 5 (Burkholderiaseminalis).

The research was arranged in a Randomized Complete Block Design (RCBD) with two factors and three blocks as replications. The first factor was shallot cultivars, namely Crok (K1), Tiron (K2), and Tuk-tuk (K3). The second factor was PGPR suspension; control treatment (B0), PGPR isolates of Bacillus methylotrophicus (B1), PGPR isolates of Bacillus amyloliquofaciens (B2), PGPR isolates of Bacillus subtilis (B3), PGPR isolates of Burkholderiacepacia (B4), and PGPR isolates of Burkholderiaseminalis (B5).

Variables observed in this research including growth parameters, i.e. seed germination, simultaneous growth of shallot seeds at seven days after planting, plant height, and number of leaves per plant in two, four, and six weeks after planting. Physiological parameters including Leaf Area Ratio (LAR), Activity of Nitrate Reductase (ANR), and chlorophyll content in five weeks after planting. Yield parameters including number of bulb, diameter of bulb (mm), and fresh weight of bulb production (gr) in eight weeks after planting. Some parameters were measured using the equationsas follows:

Leaf Area Ratio; Leaf area ratio was plant ability to produce a unit of leaf area per unit clump planting dry weight produced by plants $\left(\mathrm{cm}^{2} \mathrm{~g}^{-1}\right)$ and was calculated using formula:

$$
\mathrm{LAR}=\frac{L a}{W} \mathrm{~cm}^{2} \mathrm{~g}^{-1}
$$

whereas: LAR: Leaf Area Ratio, La: leaf area, W: Total Dry Weight

The Activity of Nitrate Reductase (ANR) (Bates et al., 1973)was a way to measure the content of nitrate contained in the plant, using a formula:

$$
\mathrm{ANR}=\frac{\mathrm{AS}}{\mathrm{A}_{0}} \times \frac{1000}{\mathrm{~B}} \times \frac{1}{\mathrm{~T}} \times \frac{500}{1000}
$$

whereas: AS: the value of solution absorbance, $\mathrm{A}_{0}$ : absorbance value of the standard (0.0106 or 0.0142$)$, B: fresh weight of leaf samples.

Chlorophyll a and b; calculated using the formula: Chlorophyll a content $=-0.00269 \times \mathrm{A} 645+0.0127 \times \mathrm{A} 663$

Levels of chlorophyll $b=0.0229 \times$ A645 $-0.00468 \times$ A663

whereas: A645 is the absorbance at a wavelength of $645 \mathrm{~nm}, \mathrm{~A} 663$ is the absorbance at a wavelength of $663 \mathrm{~nm}$ (Bates et al., 1973)

The data result were analyzed using ANOVA (Ftest) at significant level of $5 \%$. If the test results indicated a real influence or very real, the tests were to be continued by Duncan's multiple range test (DMRT) at significant level of 5\%.

\section{RESULT AND DISCUSSION}

The results showed that seed viability (germination) had no real effect, but the type of cultivar showed real effects. This was demonstrated by Tiron cultivars which had a germination percentage of $98.15 \%$, followed by Tuk-tuk cultivar and Crok. It was believed that seed germination was related to seeds' shelf life which affected the quality of seeds used in the research. Even though the seeds used were small, when the water content had reached its field capacity, then these seeds had the ability to germinate properly. While for the given PGPR treatment did not show any real effect (Table 1 ).

Simultaneously growing of seeds showed different results. Results showed that interaction between

Table 1. Shallot seed germination of Crok, Tiron, and Tuk-tuk cultivars in 7 days after planting.)

\begin{tabular}{ll}
\hline Treatments & Germination $(\%)^{*}$ \\
\hline Cultivars & $74.08 \mathrm{~b}$ \\
\hline Crok & $98.15 \mathrm{a}$ \\
Tiron & $81.48 \mathrm{~b}$ \\
Tuk-tuk & \\
\hline PGPR & $70.37 \mathrm{a}$ \\
\hline Control & $88.89 \mathrm{a}$ \\
BP25.2 & $81.48 \mathrm{a}$ \\
BP25.6 & $88.89 \mathrm{a}$ \\
BP25.7 & $88.89 \mathrm{a}$ \\
BrSM 4 & $88.89 \mathrm{a}$ \\
BrSG 5 & \\
\hline
\end{tabular}

$(-)$

Remarks: The number in one the samecolumn followed by the same letter are showed not no significantly difference in each factor,t according to Duncan Multiple Range Test with $\alpha=5 \%$; (-): tThere wais no interaction between factors being tested; $*=\mathrm{d}$ Data analyzed were transformed with $\log \sqrt{ }((\mathrm{x}+0,5))$ 


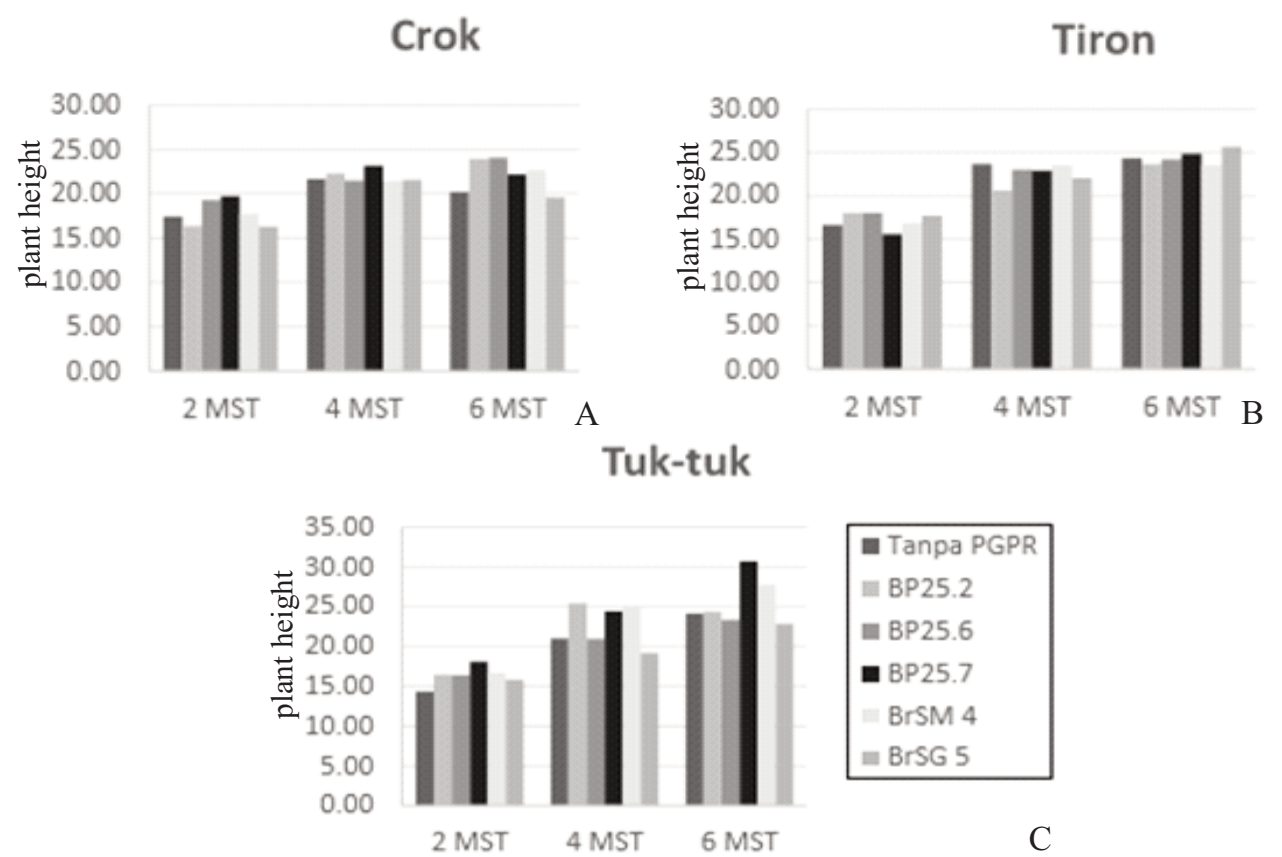

Figure 1. Plant height of shallots cultivar (A) Crok, (B) Tiron and (C) Tuk-tukat two, four, and six weeks after day planting

Table 2. Simultaneous seed growth (\%) of shallot cultivars Crok, Tiron, and Tuk-tukin 7 day after planting.

\begin{tabular}{|c|c|c|c|c|}
\hline \multirow{2}{*}{$\begin{array}{l}\text { PGPR } \\
\text { Treatment }\end{array}$} & \multicolumn{3}{|c|}{ Cultivar } & \multirow{2}{*}{ Average } \\
\hline & Crok & Tiron & Tuk-tuk & \\
\hline Control & 55.56 cde & $99.00 \mathrm{ab}$ & $33.33 \mathrm{e}$ & 62.96 \\
\hline BP25.2 & 66.67 bcde & $100.00 \mathrm{a}$ & $88.89 \mathrm{abc}$ & 88.89 \\
\hline BP25.6 & $88.89 \mathrm{abc}$ & $77.78 \mathrm{abcd}$ & $177.78 \mathrm{abcd}$ & 81.48 \\
\hline BP25.7 & $77.78 \mathrm{abcd}$ & $88.89 \mathrm{abc}$ & $88.89 \mathrm{abc}$ & 85.19 \\
\hline BrSM 4 & $44.44 \mathrm{de}$ & $88.89 a b c$ & $88.89 \mathrm{abc}$ & 74.074 \\
\hline BrSG 5 & $77.78 \mathrm{abcd}$ & $88.89 a b c$ & $77.78 \mathrm{abcd}$ & 81.482 \\
\hline Average & 92.59 & 92.59 & 75.93 & $(+)$ \\
\hline
\end{tabular}

PGPR treatment and shallot cultivars was present (Table 2). The results showed that BP25.2 isolate showed the highest rates for simultaneous parameter grow by $100.00 \%$, which was significantly different compared with control treatment (without PGPR). This showed an increasing unsynchronize grow in line with germination, which allegedly caused by the ability of rhizobacteria isolates in producing growth hormones. Bacillus BP25.2 isolate was effective at increasing growth and yield. This bacteria was used as PGPR because it possessed the ability to dissolve phosphate, fixatenitrogen, and produceauxin (IAA) and cytokinin (El Sorra et al., 2007; Gholamiand Shahsavani, 2008).

Research result showed that PGPR application had no significant effect to plant growth. However, the influence of each isolate showed a different effect
Table 3. Leaf Area Ratio and activity of nitrate reductase of shallots at five weeks after planting

\begin{tabular}{lcc}
\hline \multirow{2}{*}{ Treatments } & \multicolumn{2}{c}{ Parameters } \\
\cline { 2 - 3 } & LAR & ANR (\%) \\
\hline Cultivar & $9.54 \mathrm{a}$ & $0.84 \mathrm{a}$ \\
\hline Crok & $10.20 \mathrm{a}$ & $0.91 \mathrm{a}$ \\
Tiron & $7.15 \mathrm{~b}$ & $0.87 \mathrm{a}$ \\
Tuk-tuk & & \\
\hline PGPR & $7.36 \mathrm{a}$ & $0.87 \mathrm{a}$ \\
\hline Control & $10.10 \mathrm{a}$ & $0.92 \mathrm{a}$ \\
BP25.2 & $9.93 \mathrm{a}$ & $0.86 \mathrm{a}$ \\
BP25.6 & $9.52 \mathrm{a}$ & $0.90 \mathrm{a}$ \\
BP25.7 & $9.04 \mathrm{a}$ & $0.98 \mathrm{a}$ \\
BrSM 4 & $7.81 \mathrm{a}$ & $0.73 \mathrm{a}$ \\
BrSG 5 & $(-)$ & $(-)$
\end{tabular}

$(-)$

$(-)$

Remarks: The number in the column followed by the same letter showed no significant difference in each factor according to Duncan Multiple Range Test with $\alpha=5 \%$; (-): there was no interaction between factors tested; $*$ = data analyzed were transformed with $\log \sqrt{ }((x+0,5))$

on each observation week. In Figure 1, it appeared that BP25.7 PGPR isolate showed the best growth at two and four weeks after planting observations when it was combined with Crok cultivars. As for six weeks after planting observation, BP25.6 isolate showed highest plant growth. For Tiron cultivar, the best isolates for plant height at two weeks after planting observation were BP25.6 and BP25.7, while at four weeks after planting observation did not show any influence by PGPR isolates as seen from control plants had highest plant height. Furthermore, the 
Crok

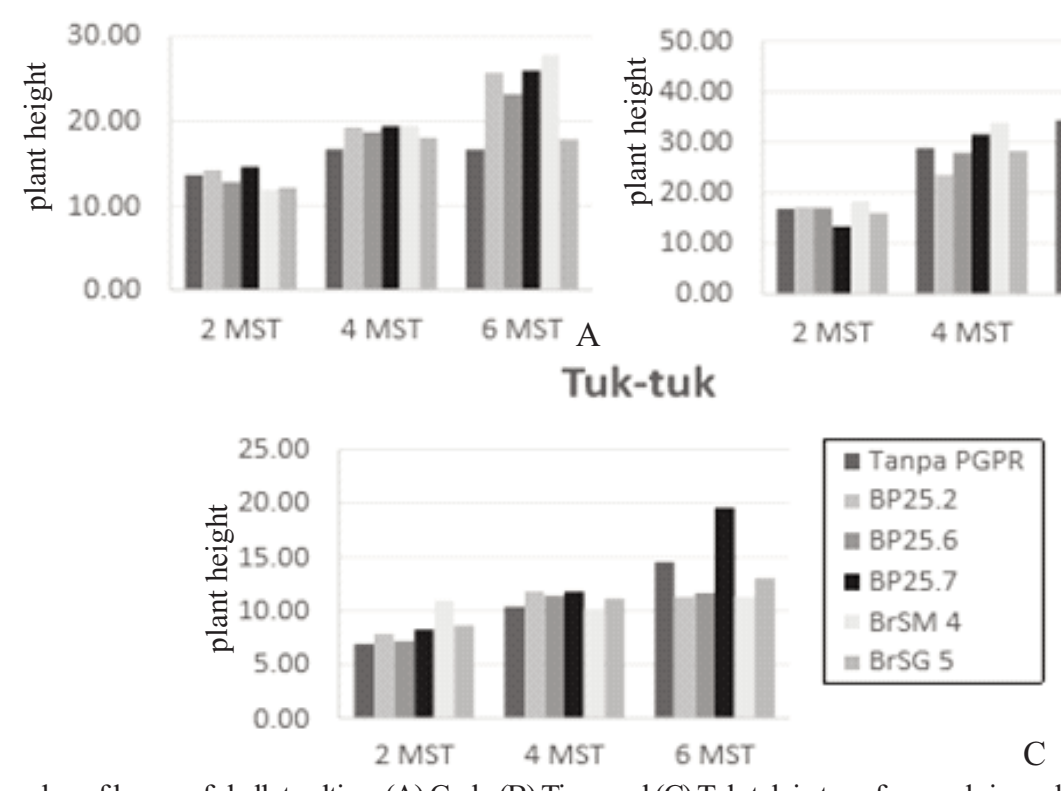

C
Tiron

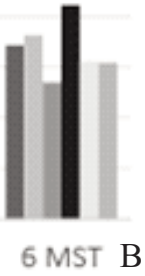

Figure 2. The number of leaves of shallot cultivar (A) Crok, (B) Tiron and (C) Tuk-tuk in two, four, and sixweeks after planting observations

highest plant height at six weeks after planting observation was resulted from application of BP25.2 isolate. For Tuk-tukcultivar, isolates BP25.7 was the best in two and six weeks after planting observations, while at four weeks after planting BP25.2 isolate resulted inhighest plant height.

PGPR isolates tested were Bacillus bacteria group that had a role in improving plant growth. High growth and development of plants occured due to cell division, cell elongation, cell formation, and the formation of new tissue required carbohydrates. Carbohydrate synthesis was heavily influenced by the ability of plants to perform photosynthesis, so the rate of growth, cell elongation, and the formation of tissue quickly, then the growth of stem, leaf and roots will running faster anyway(Husen, 2007).

Each isolates and cultivar types affected the number of plant leaves (Figure 2). Application of BP25.7 isolate caused the highest number of leaves at two and four weeks after planting observations when combined with Crok cultivars. While at six weeks after planting, BrSM4 isolate showed the highest increase in the number of leaves. Furthermore, forTiron cultivar, BrSM 4 isolate showed the highest increase in the number of leaves on observation at two and four weeks after planting. In six weeks after planting observation, BP25.7 isolate induced the highest number of leaves. For Tuk-tuk cultivar, BrSM 4 isolate showed the highest number of leaves at two weeks after planting. Meanwhile at observation on four and six weeks after planting, BP25.7 isolate induced the highest number of leaves.

Table 3 showed the results for leaf area ratio and activity of nitrate reductase at five weeks after planting. Results showed that significant effect was shown by cultivar type of PGPR treatment. Tiron cultivar showed the highest rates, which was significantly different compared withTuk-tuk cultivar, with leaf area ratio of 10.20, and followed by Crok cultivars. Leaf area ratio was one of the parameters that could be used as a reference to an increase in production of a plant. Meanwhile, PGPR treatments did not show any real influence.

The activity of nitrate reductase parameters were not influenced by cultivar types, as well as the PGPR used. In other words, the given PGPR isolates were equally able to increase the activity of nitrate reductase. The resulted differences were not much different from each other. However, a difference on chlorophyll content was found. The activity of nitrate reductase was known to be closely related to the nitrate reductase enzyme activity which had an important role in photosynthesis process in plants (Anonim, 2015).

The result for chlorophyll content showed an interaction between cultivars and types of bacterial isolates used (Table 4). The highest chlorophyll content was found in Tuk-tuk cultivar whiche were given isolate BrSM $4(0.19 \mathrm{~nm})$. The result was significantly different compared with treatment combinations of Tuk-tuk cultivar and PGPR isolate BrSG $5(0.05 \mathrm{~nm})$. The same result was found on chlorophyll b content in shallots.

Table 5 showed the results from observation on number of bulb and diameter of bulb on at eight weeks after planting. For the observations, on number of bulb and bulb diameter, shallot cultivars had 
Table 4. Chlorophyll a, b (nm) contentin shallots at fiveweek after planting

\begin{tabular}{|c|c|c|c|c|c|c|c|}
\hline \multirow{2}{*}{ Cultivar } & \multicolumn{6}{|c|}{ PGPR Treatment } & \multirow{2}{*}{ Average } \\
\hline & Control & BP25.2 & BP25.6 & BP25.7 & BrSM 4 & BrSG 5 & \\
\hline \multicolumn{8}{|c|}{ Chlorophyll a } \\
\hline Crok & $0.08 \mathrm{bc}$ & $0.08 \mathrm{bc}$ & $0.06 \mathrm{c}$ & $0.10 \mathrm{bc}$ & $0.05 \mathrm{c}$ & $0.09 \mathrm{bc}$ & 0.08 \\
\hline Tiron & $0.08 \mathrm{bc}$ & $0.12 \mathrm{abc}$ & $0.07 \mathrm{c}$ & $0.07 \mathrm{c}$ & $0.07 \mathrm{c}$ & $0.06 \mathrm{c}$ & 0.31 \\
\hline Tuk-tuk & $0.07 \mathrm{c}$ & $0.09 \mathrm{bc}$ & $0.16 \mathrm{ab}$ & $0.11 \mathrm{bc}$ & $0.19 \mathrm{a}$ & $0.05 \mathrm{c}$ & 0.08 \\
\hline Average & 0.08 & 0.10 & 0.10 & 0.09 & 0.10 & 0.07 & $(+)$ \\
\hline \multicolumn{8}{|c|}{ Chlorophyll b } \\
\hline Crok & $0.09 \mathrm{abc}$ & $0.06 \mathrm{abc}$ & $0.04 \mathrm{c}$ & $0.06 \mathrm{abc}$ & $0.05 \mathrm{c}$ & $0.06 \mathrm{abc}$ & 0.06 \\
\hline Tiron & $0.05 \mathrm{c}$ & $0.08 \mathrm{abc}$ & $0.05 \mathrm{bc}$ & $0.05 \mathrm{c}$ & $0.05 \mathrm{c}$ & $0.04 \mathrm{c}$ & 0.05 \\
\hline Tuk-tuk & $0.05 \mathrm{bc}$ & $0.06 \mathrm{bc}$ & $0.10 \mathrm{ab}$ & $0.07 \mathrm{abc}$ & $0.12 \mathrm{a}$ & $0.04 \mathrm{c}$ & 0.07 \\
\hline Average & 0.06 & 0.07 & 0.06 & 0.06 & 0.07 & 0.05 & $(+)$ \\
\hline
\end{tabular}

Remarks: The numbers followed by the same letter had no significant difference according to Duncan Multiple with $\alpha=5 \%$; $(+)$ : Significantly interaction between factors..

Table 5. Number of bulbs, diameter of bulbs, fresh weightand dry weight of bulbs at eight weeks after planting.

\begin{tabular}{lcccc}
\hline \multirow{2}{*}{ Treatments } & \multicolumn{5}{c}{ Parameters } \\
\cline { 2 - 5 } & $\begin{array}{c}\text { Number of } \\
\text { Bulbs }\end{array}$ & $\begin{array}{c}\text { Diameter of } \\
\text { Bulbs }(\mathrm{mm})\end{array}$ & $\begin{array}{c}\text { Fresh Weight of } \\
\text { Bulb }(\mathrm{g})\end{array}$ & $\begin{array}{c}\text { Dry Weight of } \\
\text { Bulb (g) }\end{array}$ \\
\hline Cultivar & $14.58 \mathrm{~b}$ & $10.77 \mathrm{~b}$ & $14.45 \mathrm{~b}$ & $3.41 \mathrm{~b}$ \\
\hline Crok & $27.83 \mathrm{a}$ & $11.85 \mathrm{~b}$ & $20.94 \mathrm{a}$ & $4.88 \mathrm{a}$ \\
Tiron & $9.61 \mathrm{~b}$ & $17.30 \mathrm{a}$ & $19.08 \mathrm{ab}$ & $3.97 \mathrm{ab}$ \\
Tuk-tuk & & & & $3.57 \mathrm{a}$ \\
\hline PGPR & $20.22 \mathrm{a}$ & $12.25 \mathrm{a}$ & $16.93 \mathrm{a}$ & $3.89 \mathrm{a}$ \\
Control & $18.33 \mathrm{a}$ & $13.38 \mathrm{a}$ & $19.86 \mathrm{a}$ & $3.68 \mathrm{a}$ \\
BP25.2 & $14.06 \mathrm{a}$ & $14.13 \mathrm{a}$ & $14.54 \mathrm{a}$ & $4.62 \mathrm{a}$ \\
BP25.6 & $17.11 \mathrm{a}$ & $14.50 \mathrm{a}$ & $21.18 \mathrm{a}$ & $4.38 \mathrm{a}$ \\
BP25.7 & $14.32 \mathrm{a}$ & $12.29 \mathrm{a}$ & $16.60 \mathrm{a}$ & $4.37 \mathrm{a}$ \\
BrSM 4 & $20.00 \mathrm{a}$ & $13.27 \mathrm{a}$ & $19.82 \mathrm{a}$ & $(-)$
\end{tabular}

$(-) \quad(-)$

$(-)$

$(-)$

Remarks: The number in the column followed by the same letter showed no significant difference in each factor according to Duncan Multiple Range Test with $\alpha=5 \%$; (-): there was no interaction between factors tested; * = data analyzed were transformed with $\log$ $\sqrt{ }((\mathrm{x}+0,5))$

significant effects. Tiron cultivars produced the highest average number of bulbs ( 27.83 bulbs) and were significantly different compared with theother cultivars used in this research. This was caused by the greatest number of Tiron seedlings cultivar which caused high number of bulbs formed. In addition, Tiron cultivars also had the ability to grow in the sandy coastal land and soil. This was a supporting factor for Tiron cultivar to produce high yield, but with small bulb size.

For bulbs diameters, Tuk-tuk cultivars showed the highest mean value of $17.30 \mathrm{~mm}$. It was significantly different compared with the other cultivars. Tuk-tuk cultivar had the lowest number of bulbs and larger bulb, thenf ollowed by Tiron cultivar. This suggested that cultivars choice in planting area also determined the volume and bulb quantity. It showed some differences in biochemistry process within the plant. According to Sufiyati et al. (2006), bulb size had a layer of relatively larger bulbs and roots had greater cross-sectional area to improve the absorption of water and nutrients for plant growth. Purnawanto (2013) added that the seeds-sized has a food reserve is relatively more that will be useful as a material forming the energy for plant growth.

PGPR treatment for each isolate for number of bulbs, diameter of bulbs, fresh weight and dry weight of bulbs showed no significant difference. In 
addition, results indicated that significant effects came from cultivars types for fresh weight and dry weight of bulbs parameters. The highest fresh weight and dry weight of Tiron bulb were respectively 20.94 $\mathrm{g}$ and $4.88 \mathrm{~g}$. The results were caused by the ability of Tiron in forming bulbs through its many tillers from each clump formed. Thus, Tiron cultivar had more ability to store water, and the high number of bulbs affected its fresh bulb weight. This could also be attributed to its ability to accumulate partially assimilates absorbed during its vegetative phase, then was used during the reproductive phase, so although becoming of the leaves during vegetative phase was high, Tiron cultivar was also capable of forming bulbs. In other words, Tiron cultivar had rapid photosynthesis rate, environment of temperature support of cell division, and water sufficiency. Tiron cultivars had a balanced life cycle (Harjadi, 2011).

\section{CONCLUSION}

Tiron had good germination ability, was able to grow and live in sandy coastal land indicated by the number of bulbs, fresh weight and dry weight of bulbs produced. BP25.2 isolate was able to increase seed grown simultaneously Tiron cultivar. BrSM 4 isolate was able to increase chlorophyll content in Tuk-tuk cultivar.

\section{ACKNOWLEDGEMENT}

The authors wish to express their gratitude to the ACIAR for the financial support for this research.

\section{REFERENCES}

Anonymous. 2015. Shallot production in Indonesia. [online] Directorate General of the Ministry of Agriculture of the Republic of Indonesia. Available at: http://m.detik.com/finance/read/ 2015/06/11/133928/2939608/4/selain-brebesini-sentra-produksi-bawang-merah-di-indonesia [Accessed 4 January 2016].

Bates, L. S., R. P. Waldren and I. D. Teare. 1973. Rapid Determination of Free Proline for Water Stress Studies. Plant and Soils, 39: 205207.

El Sorra, E. I., J. I. Domingo; T. Manuel and R. Borriss. 2007. Tryptophan-Dependen Production of indole-3-Acetic Acid (IAA) Affects Level of Plant Growth Promotion by Bacillus amyloliquefaciens FZB42. MPMI, 20(6): 619-626.

Gholami, A. S. and S. N. Shahsavani. 2008. The Effect of Plant Growth Promoting Rhizobacteria (PGPR) on Germination, Seedling Growth and Yield of Maize. Proceedings of World
Academy of Science, and Technology Engineering, 3(7): 2070-3740.

Glick, B. R. 1995. The Enhancement of Plant Growth by Free-Living Bacteria. Can. J. Microbial., 4: 109-117.

Harjadi, S. S. 1989. Basic Horticulture. Bogor: Bogor Agricultural Institute.

Harjadi, S. S. 2011. Basic of Horticulture. Bogor: Bogor Agricultural Institute.

Husen, E., R. Sarasati and D. R. Hastuti, 2007. Plant Growth Promoting Rizobacteria. [pdf] Available at: http:/balittanah.litbang.deptan.go.id/dokumentasi/ buku/pupuk/pupuk9.pdf [Accessed 24April 2016]. Kloepper, J. W., W. Mahaffee; J. A. Mcinroy and P. A. Backman. 1991. Comparative Analysis of Isolation Methods for Recovering Root-colonizing Bacteria from Roots. In C. Keel; B. Koller and G. Defago (Eds.), Plant Growth Promoting Rhizobacteria - Progress and Prospects. Interlaken, Switzerland: The Second International PGPR Workshop, pp. 252-255.

Kloepper, J.W. 1993. Plant Growth Promoting Rhizobacteria as Biological Control Agents. In F.B. Meeting, Jr. (Ed.) Soil Microbial Ecology, Applications in Agricultural and Environmental Management. New York: Marcel Dekker Inc., pp. 255 - 274. Purnawanto, A. M. 2013. Effect of Seed Size on Biomass Formation Shallot Plants at A Rate Different Applications of Nitrogen Fertilizer. Agritech, 15(1): 23-31.

Rajiman, P. Yudono; E. Sulistyaningsih and E. Hanudim. 2008. Influence Settling Soil Properties Soil Physics and Yield of Shallots On Sandy Coastal Land in Bugel KulonProgo. Agrin J., 12(1): 67-77 .

Sufiyati, Y., S. A. K. Imran, Fikrinda. 2006. Effect of Physical Size and The Number of Bulbs per Hole on The Growth and Yield of Shallots (Allium ascalonicum L.). J. Floratek., 2: 4354. 